\title{
"Challenges faced by franchise entrepreneurs operating in a volatile business environment: a case of the fast food industry in Harare, Zimbabwe"
}

\begin{tabular}{|c|c|}
\hline AUTHORS & $\begin{array}{l}\text { Knowledge Shumba } \\
\text { Stanislous Zindiye } \\
\text { Gift Donga }\end{array}$ \\
\hline ARTICLE INFO & $\begin{array}{l}\text { Knowledge Shumba, Stanislous Zindiye and Gift Donga (2017). Challenges } \\
\text { faced by franchise entrepreneurs operating in a volatile business environment: a } \\
\text { case of the fast food industry in Harare, Zimbabwe . Problems and Perspectives } \\
\text { in Management, 15(2-2), 436-444. doi:10.21511/ppm.15(2-2).2017.12 }\end{array}$ \\
\hline DOI & http://dx.doi.org/10.21511/ppm.15(2-2).2017.12 \\
\hline RELEASED ON & Friday, 01 September 2017 \\
\hline RECEIVED ON & Thursday, 02 February 2017 \\
\hline ACCEPTED ON & Monday, 15 May 2017 \\
\hline LICENSE & $\begin{array}{l}(\mathrm{cc}) \mathrm{EY}-\mathrm{NC} \\
\text { This work is licensed under a Creative Commons Attribution-NonCommercial } 4.0 \\
\text { International License }\end{array}$ \\
\hline JOURNAL & "Problems and Perspectives in Management" \\
\hline ISSN PRINT & $1727-7051$ \\
\hline ISSN ONLINE & $1810-5467$ \\
\hline PUBLISHER & LLC “Consulting Publishing Company "Business Perspectives" \\
\hline FOUNDER & LLC "Consulting Publishing Company "Business Perspectives" \\
\hline
\end{tabular}

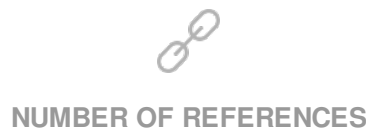

38
NUMBER OF FIGURES

0
NUMBER OF TABLES

0

(c) The author(s) 2022. This publication is an open access article. 


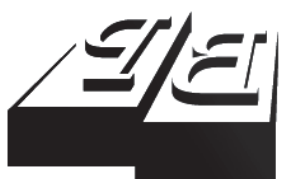

BUSINESS PERSPECTIVES

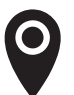

LLC "CPC "Business Perspectives" Hryhorii Skovoroda lane, 10, Sumy, 40022, Ukraine

www.businessperspectives.org

Received on: $2^{\text {nd }}$ of February, 2017 Accepted on: $15^{\text {th }}$ of May, 2017

(C) Knowledge Shumba, Stanislous Zindiye, Gift Donga, 2017

Knowledge Shumba, Student, Department of Business Management, University of Venda, South Africa.

Stanislous Zindiye, Lecturer, Department of Business

Management, University of Venda, South Africa.

Gift Donga, Student, Department of business Management, University of Venda, South Africa.

\section{(ㄷ)(1) $(8)$}

This is an Open Access article, distributed under the terms of the Creative Commons Attribution-NonCommercial 4.0 International license, which permits re-use, distribution, and reproduction, provided the materials aren't used for commercial purposes and the original work is properly cited.
Knowledge Shumba (South Africa), Stanislous Zindiye (South Africa), Gift Donga (South Africa)

\section{CHALLENGES FACED BY} FRANCHISE ENTREPRENEURS OPERATING IN A VOLATILE BUSINESS ENVIRONMENT: A CASE OF THE FAST FOOD INDUSTRY IN HARARE, ZIMBABWE

\begin{abstract}
Franchising plays a pivotal role in sustainable economic development through employment creation, improving the standards of living and increasing the growth of entrepreneurship worldwide. However, the volatile business environment in Zimbabwe has a negative impact on the growth of franchising in the fast food industry. The aim of the study was to uncover the challenges of franchising in a volatile business environment in Zimbabwe The study focused on an under studied area of franchising in the fast food industry of Zimbabwe. The study is important, as franchising can be used as a tool for economic growth and the study breaks a new ground, as no similar studies have been conducted to identify the challenges faced by franchise entrepreneurs in a volatile business environment. Ten qualitative interviews were successfully conducted with franchise entrepreneurs using face to face semi structured interviews as data collection method and thematic coding was used to analyze the collected data. The findings of the study indicate that franchise entrepreneurs face difficulties in obtaining operating licences from the Harare's City Municipal Authorities and registering their businesses. Electricity power cuts severely affect the operations of fast food businesses. The majority of the entrepreneurs do not have adequate capital to expand and grow their businesses and they fail to meet lending requirements from the financial institutions, top-most among them being the provision of collateral security accompanied by rigid application procedures for funding. Recommendations made include that the government must play an active role in promoting franchising by setting up a vibrant franchise board and speeding up the business registration process.
\end{abstract}

Keywords fast food, fast franchising, volatile business environment

JEL Classification L14, L81, L26

\section{INTRODUCTION AND BACKGROUND OF THE STUDY}

Franchising plays an important role in the growth of entrepreneurship worldwide and has a prominent position in the fast food industry. Franchising as a business model is used by entrepreneurs in the fast food industry to start their own businesses by joining well established business names and also expanding their business ventures. According to Sanghavi (1998), it has been proven that the development of franchising depends on the overall economic and political circumstances of the country and that its growth can be significantly impacted by the performance of the economy as a whole. Therefore, it should be noted that failures in franchising are possible and that franchising is not 'a panacea' to cure ailments in the business development process (Sanghavi, 1998). 
Zimbabwe's fast food franchising industry shrunk dramatically during the hyperinflation era experienced from the year 1998 to 2008 with the inflation rate reaching an official figure of 231 percent (Berger, 2008). As a result, many fast food owners failed to operate their businesses normally. Franchise entrepreneurs were faced with huge challenges of controlling costs, as prices of raw materials were continually rising within a short period of time. The period was also characterized by stock outs, as there was no guarantee of supply for raw materials, lack of working capital, high wages, credit and liquidity crunch. As a result, many well-known local and international franchised fast food outlets closed some of its branches during this period with the notable ones being KFC (Kentucky Fried Chicken), which closed its Harare and Bulawayo branches in 2007 (Ndlovu, 2014). Innscor Group who operate many franchise brands in Zimbabwe that include Pizza Inn, Chicken Inn, Chicken Express, Creamy Inn, Steers, Nando's and Mr baker also closed some of its branches during this period (Innscor, 2007).

The fast food began to improve due to economic stability after the formation of the GNU (Government of National Unity) and the adoption of the multi-currency system in 2008. It is during this period that South African brands such as Chesa Nyama and Mugg and Bean entered Zimbabwe's fast food industry. However, after the 2013 National Presidential Elections which resulted in the dissolution of the GNU, the Zimbabwean economy started to stagnate and the economy's growth rate has slowed down. Zimbabwe's local and international investors started withdrawing their investments from the economy which has seen some firms reducing their production capacity, and some closing and thousands of people losing their jobs. The World Bank projected that Zimbabwe could be headed for negative growth by 2016 if no measures were taken to halt the decline of the economy (Nyoka, 2014). Zimbabwe's economic growth has since slowed down from $3.8 \%$ in 2014 to an estimated $1.5 \%$ in 2015 and to a projected 1.5\% due to weak domestic demand, high public debt, tight liquidity conditions, drought, poor infrastructure, institutional weaknesses and an overvalued exchange rates (Nyoni, 2016; African Economic Outlook, 2016). Some businesses continue to close down operations, notably, Greatermans, which closed its doors in June 2014 after operating for more than 40 years in Zimbabwe. Greatermans survived a civil war of the 70's and the more recent hyperinflation era, but not the current operating business environment (Nyoka, 2014). Wimpy, which had managed to survive during the hyperinflation, closed its franchised branch in first street in Harare in February 2014. This is an indication that franchise businesses in the fast food industry are falling down due to the prevailing economic conditions.

Zimbabwe's macro environment characterized by political and economic instability impedes franchise entrepreneurs, fast food businesses. Franchise entrepreneurs in Zimbabwe's fast food industry are operating in a macro environment of forces and trends that shape opportunities and threats. The above prevailing conditions in Zimbabwe's macro environment make the business environment to be volatile, hence, it is against this background that the study investigated the challenges faced by franchise entrepreneurs in the fast food industry. Franchising has a significant economic impact in Zimbabwe, but little substantial research has been conducted on how the franchising operators have been operating their businesses.

\section{LITERATURE REVIEW}

De Beer (2008) defines the business environment as the sum of total of all the factors and variables which influence the establishment, growth and continued existence of the business positively and/or negatively, thereby promoting or hindering the achievement of the business's objectives. Zimbabwe's volatile business environment hinders the achievement of fast food franchise entrepreneurs' objectives.
The majority of the Zimbabwean workers live on a low disposable income. A low disposable income in a country with a slow economic growth results in workers cutting down their expenses in their everyday lives and, therefore, they reduce or cut down on fast food visits (Liutu, 2010). The economic growth rate of $2 \%$ for Zimbabwe is lower than the population growth rate of $4.3 \%$ which has increased the standard cost of living (Nyoka, 2014; Mudariki, 2013). An increase in the cost of living has resulted in a decrease in the purchasing 
power of consumers which, in turn, has hugely affected their spending behavior, as well as change on the type of products and or services they purchase. The majority of Zimbabweans live below the cost of living which is USA $\$ 567,03$ and this is due to the fact that most civil servants and private workers in the private sector earn less than USA $\$ 567$ per month (Mudariki, 2013). Karombo (2013, p. 4) states that "economic analysts said the consumer goods profitability is disposable income sensitive, driven by macro-economic factors such as GDP movement, inflation trends and employment trends which determine disposable income locally and globally". Thousands of workers in the private and public sector have lost their jobs and this trend is likely to continue due to the Supreme Court ruling in July 2015 that allows arbitrary termination of employment contracts. Close to 18 000 workers are reported to have lost their jobs three weeks after the land mark ruling which also allows employers to terminate workers contracts without retrenchment benefits (Manayiti, Nyoni, \& Dube, 2015). These job losses follow a wave of massive job losses witnessed in the year 2014 due to closure of more than 4610 companies that resulted in more than 55443 people losing their jobs in the year 2014 (Manayiti, Nyoni, \& Dube, 2015).

Starting and conducting business in Zimbabwe is not very easy for investors. In his 2015 midterm budget, the Minister of Finance Patrick Chinamasa mentioned that the main areas frustrating potential investors and compromising the country's competitiveness relate to licensing processes, multiplicity of levies authorities and delays in utility connections (NewsdzeZimbabwe, 2015). These relate to plan approvals, investment registration, permit and license issuance, connection of utilities, such as water and power. For example, formalities for setting up a typical formal housing delivery project in Zimbabwe take a minimum of 53 months (4.5 years), primarily reflecting bureaucracy and inefficiencies in national institutions and local authorities in Zimbabwe (NewsdzeZimbabwe, 2015). The World Bank's doing business indicators report for the year 2015 indicates that the average number of procedures for starting a business in Zimbabwe is nine against 7.8 in sub-Saharan Africa and 4.8 for developed countries (World Bank Group, 2015). The report further mentions that "the average time and cost for establishing a business in neighboring countries such as South Africa is 19 days and $0.3 \%$ of income per capital and Mauritius, six days and $3.6 \%$, respectively. This is against Zimbabwe's average period of 90 days and 141.2 per cent of income per capital. This is a clear indication that the Zimbabwean business environment is not very attractive to investors as compared to other neighboring countries.

It is generally accepted that a strong relationship exists between political and legal systems of a country (Louw \& Venter, 2013). The political instability of Zimbabwe is characterized by the indigenization policies, excessive direct and indirect taxation and unreliable energy power supplies. There are also high levels of corruption in Zimbabwe (Laiton, 2014). There have been a lot of accusations being levelled against top officials for being corrupt (Laiton, 2014). According to ZimSitRep (2014), Zimbabwean government's intention to deepen its involvement in business, as proposed in the Zimbabwe Agenda for Sustainable Socio-Economic Transformation (ZimAsset) policy document, also appears likely to increase the running costs of existing business. This will further add to the reluctance of new investors to invest in the country's economy.

\section{METHODOLOGY}

A qualitative design was used in this study. The qualitative research approach was ideal, since it best captured the experiences of the entrepreneurs concerned, highlighted their narratives, perceptions and the challenges they face in operating their business in Zimbabwe's volatile business environment. Ten participants took part in the study. The study followed a census approach, hence, no sample size was drawn for the study. There are approximately 40 franchised fast food outlets in Harare and the majority of these outlets are multi-owned franchised units. For example, Vinal Investments owns 3 Mugg and Beans, 2 Ocean Basket and 2 News Cafe's and Smooch outlets in Zimbabwe located in Harare, whilst all the 13 Nando's and 8 Steers outlets are owned by Innscor Group and the 3 KFC branches are owned by Country Bird Holdings (McCrea \& Pinchuck, 2000; Mbanje, 2014; Innscor, 2013). This, therefore, 
made it possible to follow the census approach for this study during the data collection phase.

Face to face semi-structured interviews were used to collect data, as they vividly captured the views of the participants through the use of an interview guide. This data collection method was ideal, as it provided the researcher the opportunity to probe further and get the finer details of the feelings and perceptions of the respondents. A thematic analysis research method was used to analyze the transcribed interviews from the respondents.

\section{FINDINGS AND DISCUSSION}

\subsection{Regulatory constraints}

All of the respondents expressed that they encountered regulatory challenges when they opened their businesses. These regulatory constraints pertain to the registration of their business, regulatory requirements and obtaining operating licences. Prospective fast food business entrepreneurs in Zimbabwe are required to obtain the take away licence and/or the restaurant licence before they start resume to operate their businesses by the municipal authorities. The take away licence allows the fast food providers to sell their meals to customers, but the customers are prohibited from eating or enjoying the meals within the fast food provider's premises. With the restaurant licence the fast food business entrepreneurs sell their meals to customers who must eat their meals or enjoy their meals within their premises.

Franchise entrepreneurs prefer to offer both the sit-ins service and take away services, hence, franchise entrepreneurs in Zimbabwe's fast food industry must be in possession of these two licences for them to operate their businesses. However, the issuing of these operating licences by the Harare Municipality to the entrepreneurs takes a long time which causes delays in them opening their fast food outlets. The findings of the study are in line with Mandizha's (2015) explanation that the delays in issuing the licences by the Harare City's Council Authorities accounts for half of the burden of starting business in Zimbabwe, as mea- sured by the World Bank in doing business in Zimbabwe. The Harare City Council accounts to 4 out of the 9 processes involved in setting up a business and these processes sum up to $54(60 \%)$ days of the 90 days that business entrepreneurs take to complete a business registration in Zimbabwe (World Bank, 2015).

Majority (70\%) of the respondents expressed that the prices charged for acquiring licences are very expensive for them and they do not reflect the state of the Zimbabwean economy. The following remark was captured to indicate franchise entrepreneurs responses. "Operating licences are very high, they need to be revised downwards to reflect the state of the Zimbabwean economy. The prices have not been revised downward ever since the dollarization of the economy".

The above is a clear indication that operating licences are less affordable to the majority (70\%) of franchise fast food operators in Zimbabwe. A further analysis of the total costs involved in a business set up in Harare revealed that the municipal licences costs $60 \%$ (\$564) of the USA $\$ 940$ cost incurred to set up a new enterprise in Zimbabwe (Mandizha, 2015). In union with the above sentiments, Sanderson (2014) also confirmed that the business operators in Harare owe the city council more than USA \$200 million, as they are failing to pay for their shop licences and rates in time.

\subsection{Lack of government support}

The majority (90\%) of the respondents believe that the government does not have a positive interest in their business activities and also indicated that their businesses have never benefitted from any government policies. These business interests relate to ensuring a conducive environment that is favorable to their business investments. The following remark was captured:

"No. I personally feel that the laws that protect the interest of the business people are very few and are not being fully implemented. For example, not enough has been done to help reduce the long processes in the issuing of business licences, municipal licences and fight corruption. The government has also failed to help promote the growth of franchising". 
It can be clearly seen from the above excerpt that the business environment that franchise entrepreneurs are operating is very volatile characterized by high levels of corruption in the issuing of business licences and Municipal licences. The respondents felt that the failure by the government to halt high levels of corruption in the issuing of the above licences is an indicator that the government has less concern on their business activities. The study confirms the predictions made by Conrad (2015) that the high levels of corruption in Zimbabwe are destroying the economy. Entrepreneurs are finding it difficult to operate in the prevailing business environment that seem to have developed a culture of corruption, bureaucracy and unfriendly regulations.

\subsection{Higher rates of unemployment}

High rates of unemployment reduce consumer spending towards fast food meals, as more and more people depend on the income of one individual person. $60 \%$ of the respondents indicated that their sales revenue have dropped due to the growing higher rate of unemployment. One of the respondents indicated that "We are experiencing a reduction in my business sales revenue, since some of our customers have lost their jobs this year, whilst some have heard their salaries reduced".

The prevailing economic conditions in Zimbabwe forces the majority of the Zimbabwean population to spend less on fast food outlets meals. Consumers can only afford to buy basic needs, hence, reducing their spending towards fast food meals, as they perceive these to be luxurious activities. This is in line with Moyo's (2014) explanation that the majority of the government workers (civil servants) cannot afford anything except basic food staff in Zimbabwe. The findings corroborates with Chimhangwa (2014) who indicated that Innscor a dominant player in the fast food industry in Zimbabwe had to close some of its branches which were recording losses as a result of the continuous reduction in the disposable income of workers. Mangudhla (2012) also indicated that Innscor had to lower their prices in order to stimulate sales revenues against a back drop of low disposable incomes for the Zimbabwean workers for them to survive in the prevailing business environment.

\subsection{Effect of electricity power supplies}

The majority (80\%) of the franchise entrepreneurs interviewed noted that their businesses are hugely affected by the electricity power cuts. They stated that the power cuts have severely affected their businesses, as they have to spend more money on fuel for their generators in order to continue operating when there is load shedding. The following remark was recorded during the interviews: "We are currently relying on our generators, as the power cuts are very frequently this year as compared to other years".

The above is a clear testimony of the prevailing situations in Zimbabwe regarding to the electricity supplies in the country. The findings are in agreement with Mhlanga's (2015) explanation that Zimbabwe has been experiencing crippling power shortages, with national demand at peak periods estimated at $2200 \mathrm{MW}$, against available generation of about $1000 \mathrm{MW}$. This, therefore, leads to massive load shedding being experienced by most of the residents including the formal businesses going for up to 18 hours without electricity (Zuze, 2015). With this prevailing load shedding, franchise businesses in Zimbabwe's volatile business environment have been forced to have back-up plans in form of electricity power generators to ensure that they continue operating normal when they experience the massive power-cuts.

In support of the above, another respondent expressed that:

"We sell pizzas and their nature demands constant supply of electricity power supply, hence, our generators automatically start when they are electricity power cuts. Our ovens need not to lose power for more than a minute whilst preparing pizzas. If this happens, we have to throw away the pizzas, as they would be of poor quality".

The above is a confirmation that franchise businesses use generators when there is load shedding, as they do not want to lose their customers to other fast food outlets. Failure to have standby generators also lead to incurring of losses as the meals that will be in the process of being prepared have to be thrown away as they either become sub-stan- 
dard, deformed or of such low quality. Some of the load shedding in some areas lasts for longer periods, hence, if they were to close their shops, they risk losing customers to other competitors. Most of the materials that are used in preparing meals in the fast food industry easily get rotten especially if they are not refrigerated, hence, most of the fast food entrepreneurs use back-up generators to ensure that their materials such as meat and vegetables do not get bad, as this will result in losses. Electricity power shortages have a negative effect on the costs of operations of franchised businesses in Zimbabwe.

\subsection{Water shortages}

$40 \%$ of the business indicated that their businesses are greatly affected by the water supplies. The following responses were captured: "Water cuts are very frequentl in this area especially in the morning between $7 \mathrm{am}$ and 10am. Despite the frequent water cuts, we still receive expensive water bills as if we are receiving normal water supplies".

The above excerpt clearly shows that the persistent problems of water supplies affect the franchise entrepreneurs, hence, they had to have back up water supplies to ensure that their businesses continue to operate normally. Water is very important for fast food operators, as it enables franchise operators to keep their places clean and hygienic. It is a vital resource as they need to continuously clean their shops when they are dirty as they continuously receive large number of customers coming in and going out every minute. Continuous water supplies ensure that hygiene is maintained in the toilets as water is needed when cleaning the toilets and its mixture with cleaning materials helps to prevent the bad smelling of the toilets. In Harare, the water distribution system was built long before independence in 1980, and has gone without proper maintenance for many years, and its pumps that have an expected lifespan of between 15 and 20 years have not been replaced since they were installed (Mangizvo \& Kapungu, 2010). This means that the water systems are dilapidated and will continuously breakdown; this translates into water shortages. As a result, residents and businesses in the city go without water for more than twelve hours daily (Mhlanga, 2015). Therefore, franchise businesses operating in Zimbabwe are severely affected by water shortages.

\subsection{Capital for growth}

Majority of the respondents $(80 \%)$ shared the common perception that their businesses do not have adequate capital for growth. They all indicated that they want to expand their businesses, but their growth ambitions are hampered by lack of adequate capital. The respondents shared these common views: "We do not have adequate capital for growth. We would like to open more branches for our businesses in Harare, but we do not have sufficient capital funds to invest or start up or set up a new branch".

"We are trying to set up a new branch in Harare, but lack of sufficient funds is hampering the opening of the new branch".

The above shows that franchise operators are limited to expand their businesses by opening new branches because of lack of adequate capital. The above confirms the findings of Gangata and Matavire (2013), and Reserve Bank of Zimbabwe (RBZ) (2006) that lack of adequate capital is one of the major constraints and continues to be a significant impediment to the creation, survival and growth of many businesses in Zimbabwe. They face challenges in obtaining funds to finance the growth of their businesses. The above findings are in contradiction with Niemann and Nieuwenhuizen's (2009) assertion that banks and other financial institutions are now aware that the odds for business success are far more favorable for franchise operations than for independent counterparts. Given the current prevailing economic conditions in Zimbabwe, franchise fast food entrepreneurs do not have adequate internal funds for growth, hence, they are in need of external funds. In an effort to access the external funds and other resources, franchise operators face many challenges to finance the growth of their businesses.

Even though the Reserve Bank of Zimbabwe lowered the interest rate, franchise fast food owners are still facing many challenges with obtaining funds to finance their business growth ambitions. This therefore, confirms Daniels and Ngwira's (1993) opinion that financial challenges handicaps the operations of business entrepreneurs. The following remarks were made regarding the availability of external funds to the franchise en- 
trepreneurs: "The application procedures are very long and these financial institutions are always demanding collateral security which I do not have".

The above is clear indication that the majority (80\%) of franchise fast food owners are facing challenges in their attempts to secure external funds for their growth from financial institutions. The above shows that the majority of the franchise operators fail to provide collateral security to financial institutions for them to be granted funds to expand their businesses. The above extracts also revealed that the application process for loans in Zimbabwe follow rigid procedures which discourage entrepreneurs to apply for loans as they perceive this to be boring. The franchise entrepreneurs still perceive the current interest to be very high, hence, they still cannot obtain loans from financial institutions despite the fact that they were recently revised downwards. The findings are endorsed by Gombarume and Mavhundutse (2012) on challenges faced by SMEs enterprise in Zimbabwe which highlighted that the cost of borrowing funds, terms and conditions of borrowing coupled with a cumbersome process to be followed in applying for financial assistance is one of the reasons why businesses fail to get financial assistance from financial institutions.

\subsection{Costs of labor on profitability}

There seemed to be general consensus that the costs of labor in Zimbabwe are very high at the moment for the majority $(80 \%)$ of the franchise entrepreneurs. The costs of labor contribute a greater percentage of the total production costs incurred by franchise operators in Zimbabwe. The following remarks were captured with regards to the labor costs: "Our labor costs are not indicative of the prevailing economic conditions. They are very expensive, which leaves us with less profit, as we try to charge lower prices for our meals".

Taking into consideration the above responses, it can be concluded that the labor costs are very high to the majority of the franchise fast food owners, hence, they should be a downward revision of the Zimbabwe's labor cost structure. A respondent indicated that the reason for the higher labor costs structure may be attributed to: "When we migrated from the Zimbabwean dollar to the multicurrency, most Zimbabweans remained with the mind-set of a hyperinflation era such that many people viewed the United States dollar as equivalent to the hyper inflated Zimbabwean dollar".

As evidenced by the above statement, the general feeling among franchise fast food owners is that workers in the fast food business are overpaid under the present volatile business environment. This is supported by Makichi (2014) who concluded that there is no correlation whatsoever between production and remunerations in Zimbabwe and this has resulted in most companies bleeding. The Zimbabwean labor costs are very high, because their cost structures are centred on the poverty datum line of USA $\$ 500$, the highest in the region which cannot match the current operation of major companies in Zimbabwe (Makichi, 2014). With the labor costs being centred on the poverty datum line in Zimbabwe their costs have eroded a greater percentage of the franchise fast food owner profits.

\section{CONCLUSION}

Franchise entrepreneurs in Zimbabwe face a problem of "red tap", that is, strict business registration process and issuing of licences. There is a lack of government support towards the growth of franchised business. The biggest challenges faced by franchise entrepreneurs are lack of capital for growth and severe electricity interruptions.

\section{RECOMMENDATIONS}

The government needs to promote a good investment climate by eliminating bureaucracy, unfriendly business regulations and by fighting corruption to encourage the growth of franchising phenomenon. The government must play an active role in reducing the total costs incurred when starting up a business 
and the number of days taken to start up a business. Load shedding must only be limited to households whilst business complexes, shopping malls and garages where some of the restaurants are located must be spared from load shedding. The government must try to attract new investors through incentives such as taxes on franchised businesses. These tax incentives schemes may include exempting new franchised businesses from paying taxes for a certain period, for example, for the first 5 years. The government must adopt the franchised business model as a tool for economic development. The Harare City's Municipality must speed up the process of issuing operating licences to business. Franchise entrepreneurs must search for other alternative sources of finance which are less expensive, for instance, borrowing from family members, selling their personal assets, family servings and also from partnerships with other franchisees and franchisors to raise funds to open new branches.

\section{REFERENCES}

1. Bates, B., Botha, M., Botha, S., Goodman, S., Ladzani, W., Vries, C., \& Vries, L. De. (2005). Business Management. Fresh Perspectives. Cape Town: Clyson Printers.

2. Berger, S. (2008). Zimbabwean Inflation Rate hits 231 million per cent. The Telegraph. 09 October 2008. Retrieved from: http://www. telegraph.co.uk/news/worldnews/ africaandindianocean/zimbabwe/3167379/Zimbabwe-inflationhits-231-million-per-cent.html

3. Chimhangwa, K. (2014). Fast foods outlets face stiff competition. The Standard. 26 January 2014. Retrieved from https://www. thestandard.co.zw/2014/01/26/fastfoods-outlets-face-stiff-competition/

4. Conrad. (2015). Corruption: A cancer eating into Zimbabwe. The Herald. 19 February 2015. Retrieved from https://www.thestandard. co.zw/2014/01/26/fast-foods-outlets-face-stiff-competition/

5. Daniels, L., \& Ngwira, A. (1993). Results of a Nation-Wide survey on Micro, Small and Medium Scale Enterprises in Malawi. GEMINI Technical Report No 53. PACT Publications, New York.

6. De Beer, A. (2008). What is Business Management? In Nieuwenhuizen, C, and Rossouw, D., Business Management a contemporary approach. Cape Town. Juta and Company.

7. Gangata, K., \& Matavire, E. H. M. (2013). Challenges facing SMEs in accessing finance from financial institutions: The case of Bulawayo, Zimbabwe. International Journal of
Applied Research and Studies, 2(7).

Retrieved from www.ijars.n

8. Gombarume, F. B., \& Mavhundutse, S. (2012). Challenges Faced by Small to Medium Scale Enterprise. A Case Study of Chitungwiza, Zimbabwe. Greener Journal of Business and Management Studies, 4(4), 103-107.

9. Innscor. (2013). Annual Report 2013. Retrieved from http://www. innscorafrica.com/?wpfb_dl=39

10. Innscor. (2007). Annual Report 2007. Retrieved from www. investinginafrica.net

11. Karombo, T. (2013). Ching Ching for Nando's, Chicken Inn. BIZCOMUUNITY.com Daily Industry News. Retrieved from http://www.bizcommunity.com/ Article/196/173/64012.html

12. Laiton, C. (2014). The birth of corruption in Zimbabwe. Newsday. Retrieved from https://www. newsday.co.zw/2014/02/08/birthcorruption-zimbabwe/

13. Liutu, R. (2010). Subway Market Research. A Thesis Submitted in partial fulfilment of the requirements of Saimma University of Applied Sciences for the requirements of the Degree of Business Administration Bachelor's Thesis. Retrieved from www.thesus. fi

14. Louw, L., \& Venter, P. (2013). Strategic Management. Developing Sustainability in Southern Africa. New York: Oxford University Press.

15. Makichi, T. (2014). Zim's labor costs too high, says Chinamasa.
Chronicle. Retrieved from www. chronicle.co.zw/zims-laoburcosts-too-high-says-chinamasa/

16. Manayiti, O., Nyoni, M., \& Dube, B. (2015) Massive Zim job losses in wake of court ruling. Mail and Guardian. Retrieved from http:// mg.co.za/article/2015-08-06-massive-zim-job-losses-in-wake-ofcourt-ruling/

17. Mandizha, T. (2015). Harare council to expedite business licensing. Newsday. Retrieved from https://www.newsday. co.zw/2015/10/01/harare-councilto-expedite-business-licensing/

18. Mangizvo, V. R., \& Kapungu, N. (2010). Urban Domestic Water Crisis in Zimbabwe. The Case of Kadoma City. Journal of Sustainable Development in Africa, 12(8), 254-263.

19. Mangudhla, T. (2012). Innscor faces stiff competition. Zimbabwean Independent. Retrieved from https://www.theindependent. co.zw/2012/10/26/innscor-facesstiff-competition/

20. Mbanje, P. (2014). Harare: The Sunshine City that lost the wow, the lustre and the vibe. The Standard. Retrieved from https://www.thestandard.co.zw/2014/04/13/hararesunshine-city-lost-wow-lustre-vibe/

21. Mboweni-De Klerk, R. C. M. (2008). Children's preference on fast foods. Dissertation submitted in partial fulfilment of the requirements for the degree of Master of Commerce in Business Management. Unpublished thesis at University of Johannesburg. 
22. McCrea, B., \& Pinchuck, T. (2000). The Rough Guide to Zimbabwe. Retrieved from https://books. google

23. Mhlanga, F. (2015). Water Shortages: Light at the end of the tunnel for Harare residents. Zimbabwean Independent. Retrieved from https://www. theindependent.co.zw/2015/07/31/ water-shortages-light-at-the-endof-the-tunnel-for-harare-residents/

24. Mhlanga, P. (2015). Zimbabwe Electricity Crisis To Worsen. The Financial Gazette. Retrieved from http://www.financialgazette.co.zw/ zimbabwe-electricity-crisis-toworsen/

25. Moyo, J. (2014). Zimbabwe's Food Entrepreneurs Cash in On a Failing Economy. Inter Press News Agency. Retrieved from http://www.ipsnews.net/2014/08/ zimbabwes-food-entrepreneurscash-in-on-a-failing-economy/

26. Mudariki, G. (2013). Cost of Living Rises. Newsday. Retrieved from https://www.newsday. co.zw/2013/10/03/cost-livingmarginally-rises/

27. Ndlovu, C. (2015). Depreciation of the rand: Impact on Zimbabwean businesses. Bulawayo24News Retrieved from http://bulawayo24. com/Opinion/Columnist/73554
28. Ndlovu, R. (2014). KFC reopens Harare branch after seven years. Business Day Live. Retrieved from www.bdlive.co.za

29. Niemann, G., \& Niewenhuizen, C. (2009). Entrepreneurship: A South African Perspective. 2nd Edition. Pretoria: Van Schaik Publishers.

30. Nyoni, M. (2016). Chinamasa growth projections 'daydreaming'. The Standard. Retrieved from https://www.thestandard. co.zw/2016/10/30/chinamasagrowth-projections-daydreaming/

31. Nyoka, S. (2014). World Bank predicts negative growth for Zimbabwe 2016. SABC News. Retrieved from http://cc.bingj.com/cache. aspx? $\mathrm{q}=$ World + Bank + predicts $+\mathrm{n}-$ egative+growth+for+Zimbabwe $+2016 . \& d=4526175721303422 \&$ mkt=en-ZA\&setlang=en-US\&w =5TDWQZi7_zwKRHTSkv8Gnn2OrJNdyAjF

32. Reserve Bank of Zimbabwe (2006). Supplement 1: developmental SME projects: intervention to support youth, women, and other disadvantaged groups: supplement to the first half 2006 monetary policy review statement. Harare: RBZ.

33. Sanderson, A. (2014). Renew licences, shop owners urged. The Herald. Retrieved from www. herald.co.zw/renew-licencesshop-owners-urged/

34. Sanghavi, N. (1998). Franchising as a Tool for Small Medium Sized Enterprise (SME) Development in Transitional Economies The Case of Central European Countries. Management Research News, 21(11). Retrieved from www.emeraldinsight.com

35. South African Economic Outlook (AEO) (2016). Zimbabwe Economic Outlook. Retrieved from www.afdb.org./en/countries/southern-africa/zimbabwe/ zimbabwe-economic-outlook/

36. World Bank Group (2015). Doing Business Going Beyond Efficiency. Comparing Business Regulations for domestic firms in 189 Economies. A World Bank Group Flagship Report. 12th Edition. World Bank. Washington.

37. ZimSitRep (2014). Zimbabwe's Economic Environment. Robertson Economics. Retrieved from http://www.zimbabwesituation.com/news/zimsit_zimbabwes-business-environmentapril-2014-robertson-economics/

38. Zuze, L. (2015). Power cuts no longer a laughing matter. Newsday. Retrieved from https:// www.newsday.co.zw/2015/09/23/ power-cuts-no-longer-laughingmatter/ 